\title{
Micropropagation and Androgenesis in Coconut: An Assessment of Sri Lankan Implication
}

\author{
H. D. D. Bandupriya ${ }^{1 *}$, S. C. Fernando ${ }^{2}$ and V. R. M. Vidhanaarachchi ${ }^{1}$
}

${ }^{\prime}$ Tissue Culture Division, Coconut Research Institute, Lumuwila, 61150, Sri Lanka

${ }^{2}$ School of Botany, University of Melbourne, Victoria 3010, Australia

*Correspondence: HD D Bandupriya.Email: dbandupriya@yahoo.com

\begin{abstract}
The coconut palm is an important cash crop mostly in the sub-tropical countries which provides almost all the necessities of life to the mankind. Genetic improvement for increased productivity is a prioritized research area of coconut palm. In vitro cloning of elite palms via somatic embryogenesis seems to be a promising method due to its potential for massive propagation. Based on the Sri Lankan experience, this paper summarizes the notable achievements towards developing a reliable protocol for clonal propagation of coconut and also dihaploid plant production. The newel explant described by Coconut Research Institute Sri Lanka (CRISL), unfertilized ovaries dissected from immature inflorescences collected from -4 stage (inflorescence to be opened in 4 months time), is a somatic tissue which causes minimal damage to the mother palm while collecting. Limited number of female flowers in an inflorescence which limits large scale culturing could overcome by callus multiplication phase to produce higher number of plants. Somatic embryogenesis and germination of somatic embryos was achieved by reduction of auxin concentration in the culture medium followed by an addition of cytokinin. AINTEGUMENTA-LIKE (ANT-like) gene isolated from coconut genome which shows higher conserved domain sequence similarities with $B A B Y B O O M$ gene will assist development of suitable molecular markers to assess the morphogenic potential of in vitro cultured coconut tissues and callus. Successful plant regeneration from cultured anthers was reported by culturing anthers at three weeks before splitting (3-WBS) inflorescence stage which contains late uninucleate microspores. Heat pretreatment of anthers for six days at $38^{\circ} \mathrm{C}$ induced androgenesis in coconut upon culturing in 2, 4-D and 1-naphthyl acetic acid (NAA) added medium. Current clonal propagation protocol is efficient when responsive genotype is in use. Further improvement to current protocol will enable commercially viable protocol for coconut micropropagation.
\end{abstract}

Key words: Somatic embryogenesis, regeneration, anther culture, acclimatization 


\section{INTRODUCTION}

The coconut palm is an important cash crop which provides almost all the necessities of life; food, drink, oil, medicine, fiber, timber, thatch, mats, fuel, and domestic utensils (Batugal, 1999; Punchihewa, 1999). It is referred as the "tree of life" because of its immense importance as a subsistence crop and because of the multiplicity of uses. The main commercial product is coconut oil which is manufactured from the fresh nut or copra. Virgin coconut oil (Bawalan and Chapman, 2006) extracted from fresh coconut flesh under low heat is considered to have high levels of natural vitamins and enzymes (Marikkar et al. 2007) and is in great demand as a medicine and in cosmetics industry worldwide.

Coconut oil competes with other vegetable oils and its production share of the world oil market has decreased from $12 \%$ in 1960 to $3 \%$ in 2005 (Warner et al. 2007) and further to $2 \%$ in 2014 (http://www.palmoilresearch. org/statistics.html). Coconut industry is currently threatened globally mainly due to industrialization, urbanization, infra-structure development, changing use of coconut land for high value cash crops, and natural disasters such as cyclones, tsunamis, droughts, spread of pests and diseases. Most coconut plantations worldwide require replanting either because of aging or diseases. Lethal yellowing (Arellano and Oropeza, 1995), the lethal disease in Africa (Eden-Greens, 1995), cadang-cadang (Hanold and Randles, 1991), Phytophthora bud rot (Joseph and Radha, 1975; San, 2004) are the main diseases that cause heavy losses in coconut plantations. Moreover, constraints such as maintaining senile plantations with low productivity, use of unimproved planting material and marginal cultural practices are also increasing threats to the coconut industry.
However, coconut is still an economically important crop and the industrial demand for lauric oil is high. Therefore, taking into account the increasing demand for coconut, measures are needed to be applied immediately for the crop improvement of coconut cultivars.

Genetic improvement for increased productivity is a prioritized research area of coconut palm. Introduction of new varieties and hybrids with superior qualities is essential for the improvement of the industry by increasing the productivity. Potential traits which can be addressed are high nut yield, tolerance to adverse environmental conditions and resistance to pests and diseases. Early flowering, high oil content, and improved response to lower fertilizer levels are also some other characters for better improvement of coconut plantations. Conventional breeding of coconut is difficult owing to long juvenile phase, long life span, inherent heterozygosity, low fruit set, single seed per fruit and high degree of cross pollination. Therefore mass selection of superior parent palms and hybridization (intervarietial) have been the major tools used in coconut breeding.

Being a predominantly cross-pollinating crop with a long life span it takes several decades to breed a new coconut variety. As it is planted at a low density (typically between 140 to $200 \mathrm{palms} / \mathrm{ha}$ ), genetic trials require large areas, thus the labor cost is high. Moreover, conventional breeding alone will not be adequate when two superior traits are crossed. Use of molecular breeding is expected to strengthen and speed up the process of breeding, while reducing costs, improving efficiency and reducing the length of the selection cycle. Although a good hybrid or variety is produced, low seed production (average 100 nuts per palm per year), and a great variability among 
seed-derived progenies are limitations in such hybrids. Therefore, alternative approaches for the propagation of improved planting material should be considered. In vitro cloning of elite palms via somatic embryogenesis seems to be a promising alternative for this purpose due to its potential for massive propagation. The advantages to be gained by eliminating the high degree of variation in yield and other selected characters occur during conventional breeding are immense and therefore vegetative propagation of coconut by means of tissue culture techniques is highly desirable. The success rate largely depends on the regeneration capacity of this species, which is known to be recalcitrant for in vitro culture (Kovoor, 1981; George and Sherrington, 1984; Rillo, 1989).

This review aims to provide specifically a summary of the advancements in micropropagation and the associated biotechnological approaches applied to coconut by critically discussing notable achievements at the Coconut Research Institute of Sri Lanka.

\section{CHOICE OF EXPLANTS}

Selection of suitable explants is a major factor which governs the successful plant regeneration of a crop in vitro. In accordance with the above statement, the explant selection plays a major role during coconut in vitro culture. A range of explants (as describe below) have been used for in vitro culture of coconut.

\section{Somatic tissues; Leaf and immature inflorescence}

Immature leaves or inflorescences have been used as initial explants for most of the studies on coconut tissue culture (Karunaratne et al. 1991; Vidhanaarachchi and Weerakoon, 1997). These were considered as the best starting material, as the performance of the mother palm is already known. It is noted that, embryogenic capacity of leaf explants is controlled by the physiological maturity. The leaf tissues obtained from 12-24 month old plants were more embryogenic but their potential loses quickly with onset of juvenility (Karunaratne et al.1991). Moreover, even within the palm, specific tissues of a leaf are responsible for producing embryogenic explants (Karunaratne et al. 1991). Inflorescence tissues are preferred over immature leaves as these contain numerous meristematic points (Verdeil et al. 1994) and there was a non-destructive sampling method available (Rillo, 1989). As in leaf tissues, physiological maturity of the immature inflorescence plays a vital role in callogenesis. In coconut, a new inflorescence opens in every 4 weeks. As a common scenario in coconut tissue culture experiments, the most recently opened inflorescence is designated as stage 0 and the next one immediately below it that had not opened so far, as stage -1 . Immature inflorescence tissues at -7 or -8 ( -7 and -8 are inflorescences to be opened in 7 and 8 months time respectively) stages have been successfully utilized for micropropagation (Vidhanaarachchi and Weerakoon, 1997) while mature inflorescence stages failed to produce embryogenic calli. When the percentage callus development of the above explants is considered, lowest performance was reported in immature leaf by giving less than $10 \%$ callus production (Karunaratne et al. 1991). Immature inflorescence gave $30 \%$ callusing (Vidhanaarchchi and Weerakoon, 1997). However, plant regeneration frequency was not at a successful rate (less than 5\%) due the difficulties encountered such as slow response of in vitro cultured tissues, high heterogeneity in tissue response, intensive browning of tissues, proliferation of roots suppressing shoot formation and low capacity for embryogenesis or callogenesis (Bandupriya et al. 2008). 


\section{Zygotic tissues;Immature embryo and plumule}

Since the efficiency of coconut tissue culture was far from adequate, zygotic tissues including immature embryo (Fernando and Gamage, 2000; KarunaratneandPeriyapperuma, 1989) and plumule (which is the embryo meristem with the first primordium : Fernando et al. 2003) have been used for in vitro plant regeneration. Compared to the somatic tissues mentioned in the previous section, plumule and immature embryo gave better in vitro response by recording $55 \%$ (Fernando, 2001) and $>75 \%$ (Weerakoon, 1998) callusing frequencies respectively. Therefore, it was used as a model system to generate further knowledge for refining protocols developed using other explants. As plumules are excised from zygotic embryos, they can only produce clones of palms with unknown performance. However, if the embryos are obtained by controlled pollination of selected parents, the clones from these embryos are likely to show many of the desired characteristics of the parent palms. Moreover, once a protocol has been developed for plumule explant, it can be used as a model for the development of protocols using other explants. Plumule culture can also be applied for the multiplication of Dikiri coconut which is currently propagated only by embryo rescue.

\section{Unfertilized ovary; a novel somatic explant}

Recently, a pioneering effort of successful plant regeneration using unfertilized ovary explants was carried out by Perera et al. (2007). Early to this study, in vitro culture of unfertilized ovary has resulted only the formation of callus and adventitious roots (Griffis and Litz, 1997). In the method described by Perera et al. (2007), unfertilized ovaries were dissected from immature inflorescences collected from -4 stage (inflorescence to be opened in 4 months time). This led to the introduction of a method which causes minimal damage to the mother palm while collecting explants. Previously, inflorescences were collected at -7 or -8 stages (Vidhanaarachchi and Weerakoon, 1997) for immature inflorescence culture which caused more damage to the palm. Thus unferitilized ovary culture allows repeated collection of explants from the same mother palm in 6-8 months (Vidhanaarchchi et al. 2013).

From a single inflorescence, the number of explants which can be cultured, vary between 6-71 (Vidhanaarachchi et al. 2013) and the average number is around 30 . This is one of the drawbacks of using unfertilized ovaries as explants and limits large scale culturing to produce higher number of plants through clonal propagation. The callus multiplication phase introduced by Perez-Nunez et al. (2006) for plumule explants was coupled with unfertilized ovary culture to enhance callogenesis (Perera et al. 2009; Vidhanaarachchi et al. 2013). Callus multiplication was witnessed in both Tall and Dwarf $x$ Tall hybrid (DT) cultivars. Tissue culture response of explants excised from each palm shows very high variation. However some palms have shown very high performance during in vitro culture producing more than 200 plantlets per inflorescence (Vidhanaarachchi et al. 2013). Attempts have been made to identify the mother palms which have high response for in vitro culture (Vidhanaarachchi et al. 2013). Furthermore, not only individual palms but also individual explants responded differently to in vitro culture (Vidhanaarachchi et al. 2013). This could be due to the presence of unfertilized ovaries of different maturity within a single inflorescence at collection (Fernando et al.2010) and also environmental conditions. Nonetheless, it is difficult to overcome this problem by improving culture conditions. Even with these drawbacks, over $70 \%$ callusing 
was recorded in ovary explants (Perera et al. 2009; Vidhanaarachchi et al. 2013) showing its amenability for callogenesis as other well performing zygotic explants. However the regeneration percentages were always far below the percentages of callusing for each explants (Fernando et al. 2000; Perera et al. 2009)

\section{SOMATIC EMBRYOGENESIS AND PLANT REGENERATION}

Even though there are reports on direct organogenesis using floral meristems (Vidhanaarachchi and Weerakoon, 1997) somatic embryogenesis is the principle mode of in vitro plant regeneration in coconut.
Somatic embryogenesis comprises of five steps which are callus induction, somatic embryo initiation, somatic embryo maturation, shoot development and rooting (Figure 1). Success of the regeneration protocol depends on each of the steps.

The basal medium CRI 72 was formulated specifically for coconut tissue culture (Karunaratne and Periyapperuma, 1989) has been successfully used for callus induction and somatic embryogenesis in all explants (reviewed in Nguyen et al. 2015).Incorporation of sucrose at a concentration ranging from $4-6 \%$ appears to be essential for somatic
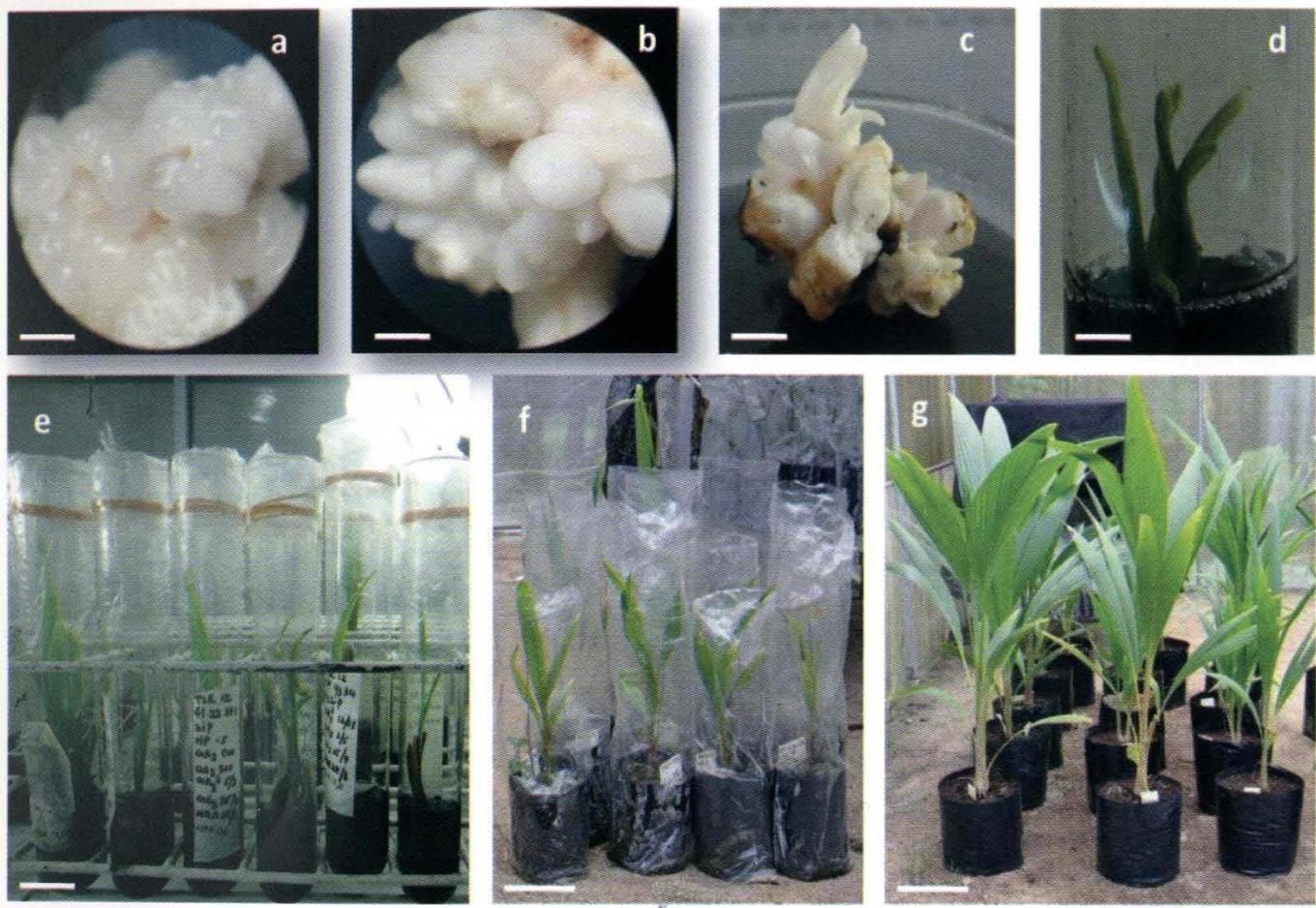

Fig.1: Somatic embryogenesis from coconut unfertilized ovary. a Ovary-derived callus produced in callogenesis induction medium (Bar $=3 \mathrm{~mm}$ ). b Somatic embryos obtained after sub culturing the calli onto somatic embryo maturation medium devoid of growth regulators $(\mathrm{Bar}=\mathbf{\mathrm { mm }})$. $\mathrm{c}$ and $\mathrm{d}$ Shoot germinationof a converted somatic embryo in shoot germination mediume Shoot and root development of the plantlet in conversion medium containing GA3 that was maintained in the dark. $f$ and $g$ Well developed complete plantlets under acclimatization 
embryo formation to occur (reviewed in Nguyen et al. 2015). Successful induction of embryogenic callus has been obtained in the presence of auxins, most commonly 2, 4-dichlorophenoxy-acetic acid (2, 4-D). The higher auxin concentrations are always used for callogenesis in the presence of activated charcoal, which adsorbs a major percentage of growth regulators (Fernando and Gamage, 2000; Perera et al. 2007; Vidhanaarachchi et al. 2013). Incorporation of $9.0 \mu \mathrm{MThidizuron}$ (TDZ) along with $100 \mu \mathrm{M} 2$, 4-D gave better embryogenic callus yield in unfertilized ovary culture (Perera et al. 2009). Establishment of cell suspension is a useful tool for rapid multiplication of callus but it requires friable callus. Attempts on the establishment of embryogenic suspensions for mass production of embryogenic calli failed due to the compact nature of coconut calli (Fernando, 2001). The calli are transferred to a medium for embryogenesis in which the auxin concentration is generally lower $(66 \mu \mathrm{M})$ than that of callus induction medium to enhance the induction of somatic embryos in calli (Fernando and Gamage, 2000; Perera et al. 2007).

The reduction of auxin concentration in the culture medium is followed by an addition of cytokinins to induce the maturation of somatic embryo and germination. Different cytokinins including benzyl aminopurine (BAP), kinetin (Kin), zeatin, zeatin riboside and isopentyl adenine (2-iP) have been tested to promote shoot regeneration (Karunaratne and Periyapperuma, 1989; Vidhanaarachchi et al. 1997; Fernando and Gamage, 2000; Perera et al. 2007). However, BAP is the commonly used cytokinin at CRISL and the effective concentration reported is $5.0 \mu \mathrm{M}$ (Fernando et al 2003, Perera et al 2007). Further development of embryos is achieved following the transfer of cultures/ calli with embryogenic structures on to a plant growth regulator free medium. Previous studies revealed that most of the embryogenic structures formed under these conditions are incomplete or abnormal (Fernando and Gamage, 2000) resulting low regeneration frequency. These structures further developed into shoot-like structures, fused shoots or other abnormalities. In addition to that, adventitious root formation and haustorial like tissue development was observed commonly. Regeneration of normal shoots which could develop into plantlets was sporadic (Fernando and Gamage, 2000).

Attempts were made to improve plant regeneration using abscisic acid (ABA) and polyamines, (spermine, putrescine and spermidine) (Weerakoon et al. 2002). ABA, a stress hormone was found to have a positive effect on the improvement of proembryo production but no improvement was achieved with the polyamines at the levels tested. A considerable increase in somatic embryo formation, their maturation and plant regeneration was observed when callus was transferred to the medium containing a moderate concentration $(5.0 \mu \mathrm{M})$ of ABA (Fernando and Gamage, 2000). Plant regeneration efficiency was further improved by $10 \%$ by incorporation of high agar induced water stress, PEG and $\mathrm{AgNO}_{3}$ in combination with $\mathrm{ABA}$ (Weerakoon, 2004). In contrast unfertilized ovary explants showed that conversion of somatic embryos into shoots is reduced when ABA is present in the somatic embryo induction medium (Perera et al. 2009). Nonetheless, it has been reported that early exposure of somatic embryos to 2iP promotes shoot regeneration (Perera et al. 2009). Production of haustorial like tissues and other abnormal structures were reduces greatly by selective sub culturing of embryogenic structures instead of culturing whole callus (Vidhanaarachchi et al. 2013). 


\section{REDUCTION OF BROWNING AND EXU- DATION OF PHENOLICS}

Production of polyphenolic substances and subsequent impairment of explants during culture process is a common constrain in coconut micropropagation. Activated charcoal has been used during culture process in order to prevent tissue browning, In spite of its advantage of adsorbing growth inhibitory substances; activated charcoal also adsorbs growth regulators especially synthetic auxins such as 2, 4-D in the medium which ultimately lead to undefined culture conditions. Different types and brands of activated charcoal differ with the origin, age and pore size thus show different adsorptive capacities. As a result, variable tissue performance and non-reproducible results have been witnessed (Ebert and Taylor, 1993). Quantitative analysis of freely available 2, 4-D in the medium in the presence of a particular batch of activated charcoal was the method to determine the optimal 2,4-D level for the given batch of charcoal (Fernando et al. 2010). Since this was not an easy task for routine application, attempts were made to develop a charcoal-free culture medium using immature embryo explants and different antioxidants (to substitute charcoal) such as ascorbic acid, citric acid, polyvinylpyrrolidone (PVP) and cysteine- $\mathrm{HCl}$ in combination with 2,4-D. Even though PVP and ascorbic acid were effective by recording more than $60 \%$ callusing, the frequency of somatic embryogenesis and plant regeneration and the growth rate was observed to be very low (Diyasena, 1998). Therefore, the use of activated charcoal became an essential component in coconut tissue culture medium. However, it is needed to use a charcoal type which has minimum character differences.

The problems associated with batch to batch character difference were minimized by using Activated coconut shell charcoal (ACSC) (Heycarb, Sri Lanka) throughout an experiment (Fernando et al. 2010). ACSC is a guaranteed source of activated charcoal with consistent characteristics and the product has been assured for having the same origin throughout and guaranteed by the manufacturer. Continuous use of ACSC for coconut somatic embryogenesis (Vidhanaarachchi et al. 2013) and androgenesis (unpublished data) showed successful replacement of branded charcoal with ACSC. In addition, frequent sub culturing of cultured explants is another successful method to reduce the accumulation of toxic polyphenolic substances(Fernando and Gamage, 2000).

\section{CHARACTERIZATION OF GENES ASSO- CIATED WITH EMBRYOGENESIS}

Research on coconut micropropagation is needed to focus on recent development of plant sequence based approaches especially genomics and functional genomics which could lead to a stepwise improvement of understanding of the genetic basis of embryogenesis and somatic embryogenesis especially somaclonal variations or polyploidy that possibly could occur. Compared to oil palm which is the palm family competitor of coconut, a very limited amount of molecular biology research has been carried out in coconut. Expression of Retinoblastoma $(\mathrm{Rb})$ gene, a cell cycle controlling gene, in embryogenic and non-embryogenic callus was studied using differential display (ddRT-PCR) technique (Fernando and Weerakoon, 2001). The results revealed that the expression of $\mathrm{Rb}$ gene in nonembryogenic callus was higher than that of embryogenic callus indicating the possibility of using $\mathrm{Rb}$ gene as a marker to screen embryogenic callus (Fernando and Weerakoon, 2001). 
Bandupriya et al., (2013) isolated AINTEGUMENTA-LIKE (ANT-like) gene from coconut genome which shows higher conserved domain sequence similarities with $B A B Y B O O M$ gene which has been previously shown a relationship with embryogenesis of brassica (Boutilier et al. 2002). Analysis of CnANT expression at different somatic embryo formation stages showed that the expression was increased at embryogenic callus stages and decreased progressively during somatic embryo germination (Bandupriya et al. 2014). Similar phenotypic effects (Bandupriya and Dunwell, 2012) as of $B B M$ (Boutilier et al. 2002)and other related AINTEGUMENTA-LIKE (ANTlike) genes (Morcillo et al. 2007; Tsuwamoto et al. 2010) and induction of regeneration in growth regulator excluded media (Bandupriya et al. 2012) were observed when $C n A N T$ was overexpressed in transgenic Arabidopsis. These findings will possibly help to develop suitable molecular markers to assess the morphogenic potential of in vitro-cultured coconut tissues and callus. It will also be possible to use the CnANT gene as a candidate to improve coconut tissue culture by genetic transformation.

\section{ANDROGENESIS IN COCONUT}

Due to the high heterozygous nature of coconut, it is not possible to apply conventional methods to get homozygous lines needed for breeding programmes. Heterogeneity of coconut results in greater variability in hybrid progenies and lack of homozygous inbred lines prevent stable propagation of elite genotypes by seed. The production of double haploid (DH) plants from microspores is a valuable technique for developing homozygous lines which can be used to accelerate crop improvement programmes. Success in in vitro haploid plant production in many species and the natural occurrence of haploid coconut embryos has promoted researchers to take efforts to produce coconut haploid plants through anther culture. Kovoor (1981) reported callogenesis in coconut anthers at an extremely low efficiency. Haibou (1981) made attempts to induce direct embryogenesis in microspores and observed development of first proembryoidal stages in a significant percentage of cultured anthers. However, these structures failed to develop further. Thanh-Tuyen and de Guzman (1983) reported formation of embryos at low frequencies (less than 1\%) from cultured anthers. Monfort (1985) also obtained a few anther derived embryos, however no plantlet regeneration was reported. Successful plant regeneration from cultured anthers was first reported by Perera et al. (2008).

\section{Microspore developmental stage}

As in all other crops or plants, the developmental stage of microspores is critical for coconut androgenesis. Late uninucleate stage microspores bearing anthers are best for androgenic induction in many crops (Chen et al. 2001; Chathurvedi et al. 2003; Kim et al. 2004). There was a need of establishing a correlation between the microspore developmental stage and the age of the inflorescence in order to provide simple and practical method to collect anthers for androgenic experiments. A histological study revealed the presence of late uninucleate microspores in anthers at three weeks before splitting (3-WBS) inflorescence stage (Perera 2003) thus it is easy to collect anthers for routing culturing without going for detailed histological studies prior to in vitro culture.

\section{Stress Treatment}

Stress treatment is essential for the divergence of microspores from normal gametophytic developmental pathway to a sporophytic pathway to produce embryos and 
subsequently haploid or DH plants (Germana, 2006). Heat pretreatment of anthers for six days at $38^{\circ} \mathrm{C}$ induced androgenesis in coconut (Perera et al. 2008) in comparable with Monfort (1985) where a pretreatment of anthers of coconut at $35^{\circ} \mathrm{C}$ for 1 week induced development of embryos at a low frequency. Thanh-Tuyen (1985) observed androgenesis in coconut anthers pretreated at $7^{\circ} \mathrm{C}$ for 7 days or $14{ }^{\circ} \mathrm{C}$ for 4 days. However, cold pretreatments given to anthers have not induced androgenesis in a recent study (Perera et al. 2008).

\section{In vitro culture conditions}

In vitro culture conditions for androgenesis such as culture medium and anther density have also been optimized (Perera et al. 2008; Perera et al. 2009). Detailed study on the effect of growth regulators on the induction of calli/embryos in cultured anthers have been conducted using three auxins [1-naphthalene acetic acid (NAA), indoleacetic acid (IAA), picloram] and three cytokinins [2-isopentyl adenine (2-iP), kinetin, zeatin] either alone or in combination with 2,4-dichlorophenoxyacetic acid (2,4-D), using modified Eeuwens $\mathrm{Y}_{3}$ liquid medium as the basal medium. It was shown that 2, 4-D and $2 \mathrm{iP}$ alone could give rise to a high frequency of anther-derived calli/embryos, while incorporation of $100 \mu \mathrm{M}$ NAA with 100 $\mu \mathrm{M} 2$, 4-D further enhanced the frequency of calli/ embryo production. However, IAA and picloram showed negative and harmful effects (Perera et al. 2009). Once the embryos/calli are produced, reduction of auxins is needed for the induction of somatic embryos. This is achieved by subculturing embryos/calli in to Y3 medium containing $66 \mu \mathrm{M} \mathrm{2,4-D.} \mathrm{Upon} \mathrm{transferring}$ of somatic embryos in to maturation medium ( $\mathrm{Y}_{3}$ medium without growth regulators) and germination medium $\left(\mathrm{Y}_{3}\right.$ medium containing $5 \mu \mathrm{M}$ BAP and $0.35 \mu \mathrm{M} \mathrm{GA}_{3}$ ), plantlets were regenerated at low frequencies ranging from $0 \%$ to $7 \%$ (Perera et al. 2009).

One of the drawbacks limiting the success of the androgenesis protocol is the development of hyperhydric structures which are characterized by brittleness and vitrification (Perera et al. 2011). Attempts have been made to reduce hyperhydricity by increasing the phytagel concentration in the medium (Perera et al. 2011). This study showed that the occurrence of vitrification could be reduced by half when the embryos were subcultured onto embryo maturation medium supplemented with $0.5 \%$ phytagel compared to the control medium which contained $0.25 \%$ phytagel (Perera et al. 2011). Maximum reduction of vitrifications was observed when embryos were exposed to maturation medium supplemented with $0.5 \%$ phytagel for 21 days (Perera et al.2011). It has also shown the importance of identifying the correct maturity stage of the embryo for subculturing onto the maturation medium in order to get a higher frequency of plant regeneration (Perera et al. 2011).

\section{ROOT INDUCTION, ACCLIMATIZATION AND FIELD TRANSFER OF IN VITRO RAISED COCONUT PLANTS}

Initiation of roots in vitro and subsequent survival of plantlets in the soil is very important in any micropropagation protocol. The role of auxins in root development is a known fact. Usually there is sufficient cytokinin residual in shoots to give the auxin to cytokinin balance for the initiation of roots in vitro. Therefore little or no cytokinin is needed for root initiation. In coconut, majority of shoots produced roots spontaneously without any exogenous growth regulator application (Fernando and Gamage, 2000). When root formation is not spontaneous, a pulse treatment with $500 \mu \mathrm{M}$ IAA was 
sufficient for root induction (Fernando and Gamage, 1994; Fernando and Gamage, 2000).

Acclimatization is a major bottleneck in most of the tissue culture techniques because of the shock or stress which the in vitro raised plants experience when they are transferring from in vitro conditions to natural environment. In spite of low regeneration frequency, a high rate of plant loss when transferred to ex vitro conditions also hampers the large scale plant production of coconut through tissue culture. The leaves with low or no developed cuticular wax, low level of photosynthetic pigment sand impaired stomatal mechanism are some of the characteristics of in vitro raised plantlets. This is common also to coconut plants produce in vitro. The growth of micropropagated coconut plants is slow at the initial stages due to above characteristics. However, vegetative growth after acclimatization and field transfer was comparable to that of seed nut-derived coconut plants after two years of field growth (Fernando et al. 2004).

\section{PERFORMANCE OF MICROPROPA- GATED COCONUT PLANTS}

Successfully acclimatized hundred and forty clonal plants derived through various explants (Table 1) were field planted at different sites belongs to Coconut Research Institute (Bandirippuwa Estate and Pallama Seed Garden) and Coconut Cultivation Board (Lenawa and Daisy Valley Estates) in Sri Lanka. Field establishment and maintenance were carried out as per the CRISL recommendations (Mahindapala and Pinto, 1991). When the performance of tissue cultured plants were compared with embryo culture plants during acclimatization, it was revealed that the small size of clonal plants at the time of ex-vitro transfer make them take prolonged acclimatization duration (Fernando et al. 2004). After due hardening, the micropropagated plants gradually overcome the morphological inadequacies and adapted to ex vitro conditions (Fernando et al. 2004).

Table 1: Number of clonal plams derived through different explants in the field

\begin{tabular}{lc}
\hline Explant Type & Total Number of Plants \\
\hline Immature embryo callus & 50 \\
Plumule callus & 69 \\
Unfertilized ovary callus & 11 \\
Meristem callus & 8 \\
Tender leaf callus & 2 \\
Immature inflorescence callus & 1 \\
\hline
\end{tabular}


Identification of somatic clones derived from tissue cultured plantlets, with respect to their trueness to the donor palm or within the progeny is very essential when developing a tissue culture protocol. Clones derived through immature embryo or plumule cultures have been confirmed for the absence of variants among plants within clones by microsatellites or simple sequences repeats (SSR) (Fernando et al. 2004). However this report does not compare the regenerants with their mother palms. Bandupriya et al. (Unpublished Data) reported the true-to-type conformity of tissue cultured coconut plants derived from unfertilized ovaries not only among the progeny but also with the mother palm and ensures the feasibility of the developed protocol for large scale plant production.

\section{CONCLUSION AND FUTURE DIREC- TIONS}

Significant progress aimed towards the clonal propagation of coconut has been made, but still there is a long way to go in this direction until we reach a commercially viable protocol. However, so far important advances have been materialized in coconut regeneration system.

The influence of genotype has handicapped micropropagation of coconut and this is one area which needs serious attention. Molecular approaches would assist improving protocols by modifying the culture medium and growing conditions or by introducing methods for the selection of appropriate explants or pre conditioning of explants. In addition to somatic embryogenesis which enables the production of large numbers of elite genotypes for commercial exploitation, tissue culture methods also has the potential of providing a basis for research into genetic transformation of coconut.Transformation of genes that affect in vitro regeneration could lead to an efficient regeneration system of somatic embryogenesis in coconut. The coconut shoot multiplication rate obtained so far is low and it is important to bring about further improvements to the existing tissue culture protocol such as incorporation of liquid culture system or 'bioreactor'. Few groups have already started working on liquid culture for in vitro propagation of palms such as oil palm (Gorret et al. 2004) date palm (Othmani et al. 2009) and peach palm (Steinmacher et al. 2011).

Furthermore, in vitro and ex vitro acclimatization is also an important aspect for micropropagated coconut. It is necessary to define the plant quality standard to characterize the in vitro plant quality and to estimate the establishment of plants in an accurate and economic way. Moreover, a suitable quality control strategy is necessary to ensure the performance of the coconut plants and the genetic fidelity of clonal planting stocks. Several areas of work in the tissue culture of coconut have opened up new vistas and much progress could be expected in the future.

\section{ACKNOWLEDGEMENT}

Authors wish to acknowledge Coconut Research Institute, Sri Lanka for the financial support and staff of the Tissue Culture Division, CRISL for assistance in in vitro culture. 


\section{REFERENCES}

Arellano J. and Oropeza C. (1995). Lethal yellowing. In: Oropeza C, Howard FW, Ashburner GR (eds) Lethal yellowing research and practical aspects. Kluwer Academic Publishers, Dordrecht, The Netherlands

Bandupriya H.D.D. and Dunwell J.M. (2012).Overexpression of CnANT, coconut BABYBOOM homologue alters plant growth and morphology in transgenic Arabidopsis plants. Tropical Agricultural Research23 (3): 249-260

Bandupriya, H.D.D., Gibbings, J.G. and Dunwell, J.M. (2013). Isolation and characterization of an AINTEGUMENTA-like gene in different coconut (Cocos nucifera L.) varieties from Sri Lanka. Tree Genetics and Genomes 9 (3): 813-827.

Bandupriya H.D.D., Gibbings J.G. and Dunwell J.M. (2014).Overexpression of coconut AINTEGUMENTA-like gene, CnANT, promotes in vitro regeneration in transgenic Arabidopsis Plant Cell Tissue and Organ Culture. 116 (1):67-79

Bandupriya H.D.D., Weerakoon L.K., Ranasinghe C.S. and Fernando W.P.K.K. (2008).Changes in soluble sugars, sugar profile, starch and proline in developing coconut (Cocos nucifera L.) inflorescences. CORD 24 (1); 54-60

Batugal P.A. (1999). The role of international cooperation in the development of biotechnology in coconut. In: Current Advances in Coconut Biotechnology. (Eds. C. Orapeza, J-L.Verdeil, G.R. Ashburner, R. Cardena andJ.M Santamaria) pp. 19-30,Kluwer Academic Publishers, The Netherlands

Bawalan D.D. and Chapman K.R. (2006). Virgin coconut oil; production manual for macroand village-scale processing. FAO. Thammada Press, Bangkok

Boutilier K., Offringa R.,, Sharma V.K.,, Kieft H., Ouellet T., Zhang L., Hattori J., Liu C-M., van Lammeren A.A.M., Miki B.L.A., Clusters J.B.M. and van Lookeren Campagne M.M. (2002). Ectopic expression of $B A B Y B O O M$ triggers a conversion from vegetative to embryonic growth. Plant Cell 14: 1737-1749

Chaturvedi R., Razdan, M.K.and Bhojwani S.S. (2003).Production of haploids of neem (Azadirachtaindica A. juss.) by anther culture. Plant Cell Reports. 21: 531-537

Chen Q.F., Wang C.L., Lu Y.M., Shen M., Afza A., Duren M.V. and Brunner H. (2001). Anther culture in connection with induced mutations for rice improvement. Euphytica 120:401408 
Diyasena R.A.C.N.M. (1998). Development of a charcoal free protocol for callogenesis and somatic embryogenesis in immature embryo explants of coconut (Cocos nucifera L.). M.Sc Thesis, University of Colombo, Colombo.

Ebert A., Taylor F. and Blake J. (1993). Changes of 6 benzylaminopurine and 2,4 dichlorophenoxyacetic acid concentrations in plant tissue culture media in the presence of activated charcoal. Plant Cell, Tissue \& Organ Culture 33 (2):157-162

Eden-Greens (1995) A brief history of lethal yellowing research. In: Lethal yellowing research and practcal aspects.(Eds.C. Orapeza, F.W. Howard \&G.R. Ashburner) pp. 17-33 Kluwer Academic Publishers, The Netherlands.

Fernando S.C. (2001). Studies on in vitro somatic embryogenesis of Cocos nucifera L. (coconut). PhD Thesis, University of Colombo, Sri Lanka.

Fernando S.C. and Gamage C.K. (2000). Abscisic acid induced somatic embryogenesis in immature embryo explants of coconut (Cocos nucifera L.). Plant Science. 151: 193-198

Fernando S.C and Gamage C.K. (1994) Clonal propagation of coconut: Improved culture conditions for rhizogenesis. Cocos 10: 20-25

Fernando S.C., Santha S. and Hewarathna D.J.A. (2010) Potential use of coconut shell charcoal in tissue culture media of Cocos nucifera L. Journal of the National Science Foundation of Sri Lanka 38 (3):181-185

Fernando S.C., Verdeil J-L., Hocher V., Weerakoon L.K. and Hirimburegama K.H. (2003). Histological analysis of plant regeneration from plumule explants of Cocos nucifera L. Plant Cell Tissue and Organ Culture 72: 281-284

Fernando S.C., Vidhanaarachchi V, Santha E.S. and Weerakoon L.K. (2010).Report of the Tissue Culture Division, Annual Report, Coconut Research Institute.

Fernando S.C. and Weerakoon L.K. (2001). Report of the Tissue Culture Division, Annual Report, Coconut Research Institute. pp 174.

Fernando S.C., Weerakoon L.K., PereraP.I.P., Bandupriya H.D.D., Ambagala I.E.,Gamage C.K.A., Santha E.S., Gunathilaka T.R. and Perera L. (2004). Genetic fidelity and ex vitro performance of tissue-cultured coconut plants.In Proceedings of the International conference of the Coconut Research Institute of Sri Lanka -Part II (Abstracts) 19. (Eds: T S G Peiris and C S Ranasinghe). CRI, Lunuwila, Sri Lanka. 
Gorret N., Rosli S.K., Oppenheimb S.F., Willis L.B.,Lessard P.A., Rha C.K. and Sinskey A.J. (2004). Bioreactor culture of oil palm (Elaeis guineensis) and effects of nitrogen source, inoculum size, and conditioned medium on biomass production. Journal of Biotechnology 108:253-263.

Germana MA (2006) Doubled haploid production in fruit crops. Plant Cell Tissue and Organ Culture 86:131-146.

George E.F. and Sherrington P.D. (1984). Plant propagation by tissue culture: handbook and directory of commercial laboratories. Exegetics, Basingstoke, $709 \mathrm{p}$

Griffis J.L. and Litz R.E. (1997) Advances in the in vitro morphogenesis of several coconut (Cocosnucifera L.) tissues in Florida. Proceedings of the international cashew \& coconut conference, Tanzania, pp 349-357

Haibou K.T. (1981). La culture in vitro des tissus de cocotier (cocosnuciféra L.). PhD Thesis, University of Paris.

Hanold D. and Randles, J. W. (1991). Cadang-cadang disease and its viroid agent. Plant Disease. $75: 330-335$

Hocher V., Verdeil J.-L., Rival A. and Hamon S. (1999). Application of in vitro techniques to the conservation and propagation of coconut palms. In:Current Advances in Coconut Biotechnology (Eds. C. Oropeza, J-L.Verdeil, G.R. Ashburner, R. Cardeña \& J.M. Santamaria) pp. 267-278, Kluwer Academic Publishers, The Netherlands.

http://www.palmoilresearch.org/statistics.html. Accessed in December 2015

Joseph T. and Radha K. (1975). Role of Phytophthera palmivora in bud rot of coconut. Plant Disease Reports 5: 1014-1017

Kim M., Kim J., Yoon M., Choi D.I. and Lee K.M. (2004). Origin of multicellular pollen and pollen embryos in cultured anthers of pepper (Capsicum annuum). Plant Cell, Tissue and Organ Culture77:63-72.

Mahindapala R. and Pinto J. L. J. G. (1991). Coconut Cultivation, CRI, Sri Lanka.

Marikkar J.M.N., Jayasundara J.M.M.A., Prasadika S.A.H., Jayasingha C.V.L. and Premakumara G.A.S. (2007) Assessment of stability of virgin coconut oil during deep frying. CORD 23: $62-70$

Monfort S. (1985) Androgenesis of coconut: embryos from anther culture. Z Pflanzenzuchtg 94:251-254 
Morcillo F., Gallard A., Pillot M., Jouannic S., Aberlenc-Bertossi F., Collin M., Verdeil J-L. and Tregear J.W. (2007). EgAP2-1, an AINTEGUMENTA-like (AIL) gene expressed in meristematic and proliferating tissues of embryos in oil palm. Planta 226: 1353-1362

Nguyen Q,T., Bandupriya H.D.D., Villalobo A.L.,Sisunandar S., Foale M. and Adkins S.W. (2015). Tissue culture and associated biotechnological interventions for the improvement of coconut (Cocos nucifera L.): a review. Planta DOI 10.1007/s00425-015-2362-9

Othmani A., Bayoudh C., Drira N. andTrifi M. (2009). In vitro cloning of date palm Phoenix dactylifera L., CV. DegletBey by using embryogenic suspension and temporary immersion bioreactor (TIB). Biotechnological Equipment 23(2):1181-1188

Perera P.I.P., Hocher V., Verdeil J-L., Bandupriya H.D.D., Yakandawala D.M.Y. and Weerakoon L.K. (2008). Androgenic potential of coconut (Cocos nucifera L.). Plant Cell Tissue and Organ Culture 92: 293-302

Perera P.I.P., Yakandawala D.M.Y., Hocher V., Verdeil J-L. and Weerakoon L.K. (2009). Effect of growth regulators on microspore embryogenesis in coconut anthers. Plant Cell Tissue and Organ Culture 96: 171-180

Perera P.I.P. (2003) Cytological examination of pollen development for microspore and anther culture of coconut (Cocos nucifera L.) cv Sri Lanka Tall. Cocos 15:53-59

Perera P.I.P., Hocher V., Verdeil J-L., Doulbeau S., Yakandawala D.M.Y. and Weerakoon L.K. (2007) Unfertilized ovary: a novel explant for coconut (Cocos nucifera L.) somatic embryogenesis. Plant Cell Reports 26: 21-28

Perera, P. I. P., Kularatne, J. D. J. and Weerakoon, L. K. (2011).Effect of gelling agent and selective subculturing on hyperhydricity in anther-derived coconut embryos.CORD27(2) 26-37.

Perez-Nunez M.T., Chan J.L., Saenz L., Gonzalez T., Verdeil J-L. and Orapeza C. (2006) Improved somatic embryogenesis from coconut (Cocos nucifera L.) plumule explants cultured in vitro. In Vitro Cellular and Developmental Biology-Plant 42: 37-43

Punchihewa P.G. (1999) Current status of the coconut industry. In: Current Advances in Coconut Biotechnology (Eds. C. Orapeza, J-L.Verdeil, G.R. Ashburner, R. Cardena andJ.M Santamaria) pp. 3-17, Kluwer Academic Publishers, The Netherlands.

Rillo E.P. (1989).A non-destructive technique for collecting immature inflorescences for tissue culture. Philippine Journal of Coconut Studies 14: 16-17. 
San J-B.N. (2004). The distribution and proression of phytophthora rot disease of coconut in selected areas in the Philippines. In: Diversity and management of Phytophthora in Southeast Asia. (Eds. A. Drenth \&D.I.Guest). Australian Centre for International Agricultural Research (ACIAR) Philippines.

Steinmacher D.A., Guerra M.P., Saare-Surminski K. and Lieberei R. (2011). A temporary immersion system improves in vitro regeneration of peach palm through secondary somatic embryogenesis. Annals of Botany 108:1463-1475

Tsuwamoto R., Yokoi S. and Takahata Y. (2010).Arabidopsis EMBRYOMAKER encoding an AP2 domain transcription factor plays a key role in develpomental change from vegetative to embryonic phase. Plant Molecular Biology 73: 481-492

Thanh-Tuyen N.T. (1985). Anther culture: its prospects to coconut improvement. Philippine Journal of Crop Science 10:28-35

Thanh-Tuyen N.T. and De Guzman E.V. (1983). Formation of pollen embryos in cultured anthers of coconut (Cocos nucifera L.). Plant Science Letters 29:81-88.

Karunaratne S., Gamage C. and Kovoor A. (1991). Leaf maturity, a critical factor in embryogenesis. Journal of Plant Physiology 139: 27-31.

Karunaratne S.and Periyapperuma K. (1989). Culture of immature embryos of coconut (Cocosnucifera L.): callus proliferation and somatic embryogenesis. Plant Science 62: $247-253$

Kovoor A. ( 1981) Palm tissue culture: state of art and its application to the coconut. FAO Plant production and protection paper, Rome

Verdeil J-L., Huet C.,Grosdemange F. and Buffard-Morel J. (1994) Plant regeneration from cultured immature inflorescence of coconut (Cocos nuciferaL.): evidence for somatic embryogenesis. Plant Cell Rep 13:218-221

Vidhanaarachchi V.R.M., Fernando S.C., Perera P.I.P. and Weerakoon L.K. (2013).Application of un-fertilized ovary culture to identify elite mother palms of Cocos nucifera L. with regenerative potential. Journal of the National Science Foundation of Sri Lanka.41 (1): 29-34

Vidhanaarachchi V.R.M. and Weerakoon L.K. (1997). Callus induction and direct shoot formation in in vitro cultured immature inflorescence tissues of coconut. Cocos 12: 39-43. 
Warner B., Quirke D. and Longmore C. (2007). A review of the future prospects for the world coconut industry and past research in coconut production and product. ACIAR, Canberra, Australia

Weerakoon L.K. (1998) Report of the Tissue Culture Division, Annual Report, Coconut Research Institute.

Weerakoon L.K. (2004). Coconut tissue and embryo culture in Sri Lanka: current developments and future challenges. In: Peiris TSG, Ranasinghe CS (eds) Proceedings of the international conference of the Coconut Research Institute of Sri Lanka CRI, Lunuwila, Sri Lanka, pp 41-61

Weerakoon L.K.,Vidhanaarachchi V.R.M., Fernando S.C., Fernando A. and Gamage C.K.A. (2002). Increasing the efficiency of embryo culture technology to promote coconut germplasm collecting and exchange in Sri Lanka. In: Engelmann F, Batugal P, Oliver J (eds) Coconut embryo in vitro culture: part II. IPGRI-APO, Malaysia, pp 27-40 